\title{
ÖRNEK UYGULAMALARLA ÇOK KRITERLI KARAR VERME YÖNTEMLERI
}

Dr. Serap TEPE 


\section{(C) Copyright 2021}

Bu kitabın, basım, yayın ve satış haklarn Akademisyen Kitabevi A.Ş.'ne aittir. Anılan kuruluşun izni alınmadan kitabın tümü ya da bölümleri mekanik, elektronik, fotokopi, manyetik kağıt ve/ veya başka yöntemlerle çoğaltılamaz, basılamaz, dağıtılamaz. Tablo, şekil ve grafikler izin alınmadan, ticari amaçh kullanılamaz. Bu kitap T.C. Kültür Bakanlı̆̆ bandrolü ile satılmaktadır.

ISBN

978-625-7401-56-2

\section{Kitap Adı}

Örnek Uygulamalarla Çok Kriterli Karar Verme Yöntemleri

\section{Yazar}

Dr. Serap TEPE

\section{Yayın Koordinatörü}

Yasin DİLMEN

Sayfa ve Kapak Tasarımı

Akademisyen Dizgi Ünitesi

Yayıncı Sertifika No

47518

Baskı ve Cilt

Vadi Matbaacılık

Bisac Code

COM077000

DOI

10.37609/akya.817

\section{GENEL DAĞITIM}

Akademisyen Kitabevi A.Ş.

Halk Sokak 5 / A

Yenişehir / Ankara

Tel: o312 4311633

siparis@akademisyen.com

\section{www.akademisyen.com}


Annesini her daim kitaplarla paylaşmak zorunda kalan Elif Berra' ya... 


\section{ÖNSÖZ}

Karar verme gücü sahip olduğumuz önemli güçlerden biridir. Doğru kararlar tecrübe ile, tecrübe ise yanlış kararlarla kazanılır. Karar verme, bir alternatifin mümkün diğer tüm alternatifler arasından seçilmesiyle gerçekleşen bir işlemler bütünüdür. Her karar verme işlemi bir hareketle sonuçlansın veya sonuçlanmasın, mutlaka nihai bir seçim ortaya koyar. Detaylandırmak gerekirse; karar verme, karar vericinin tercih, tecrübe, bilgi, tutum ve değerlerine göre bir durum için alternatifleri belirlemesi ve onlar arasından seçim yapmasıdır. Karmaşık, bilgi ve yorum gerektiren karar durumları düşünüldüğünde birbirleri ile çelişen ya da birbirlerini etkileyen kriterler ve tüm olası alternatifler arasında sonuca ulaşmanın aslen bilimsel bir alt yapı gerektirdiği görülmektedir.

Karar verme birçok bilim alanı ile kesişimi olan geniş kapsamlı bir bilim dalıdır. Bu bilim dalında yer bulan ve karar vericinin daha verimli karar almasına destek olan Çok Kriterli Karar Verme Yöntemleri bu çalışma kapsamında örnek uygulamalarla ele alınmıştır.

Eserin tasarımı ve yayın aşamasında gösterdiği ilgiden dolayı Akademisyen Yayınevi’ne teşekkür eder, çalışmanın hem Türkçe literatürde duyulan gereksinimi karşılamasını hem de konuya ilgi duyan tüm araştırmacılara faydalı olmasını temenni ederim.

Serap TEPE
stanbul, 2021 


\section{IÇiNDEKILER}

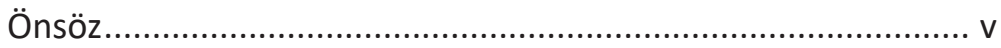

İ̧̧indekiler ..............................................................................vii

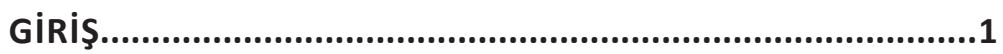

ANALiTiK HIYERARŞi SÜRECI...........................................3

AHP İçin Örnek Uygulama .................................................... 7

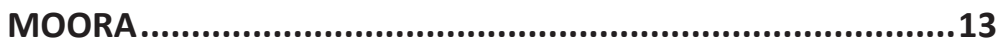

Moora Oran Metodu ........................................................... 15

Moora Ağırlıklı Oran Metodu ........................................... 15

Moora Referans Noktası Metodu ...................................... 16

Moora İçin Örnek Uygulama ............................................ 16

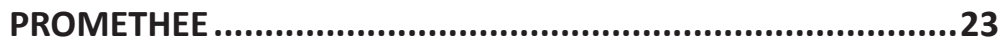

Promethee İçin Örnek Uygulama ....................................... 25

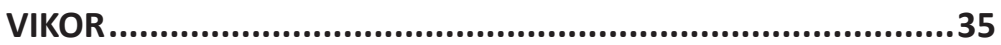

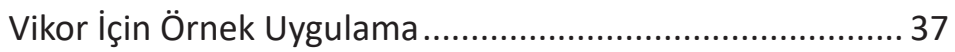

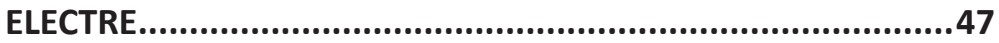

Electre İçin Örnek Uygulama ................................................. 49 


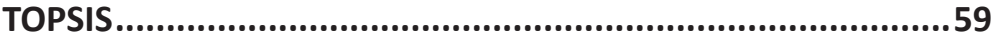

Topsis İçin Örnek Uygulama .............................................. 61

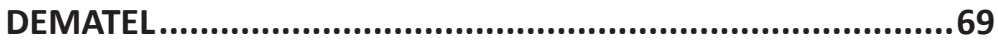

Dematel İçin Örnek Uygulama............................................ 72

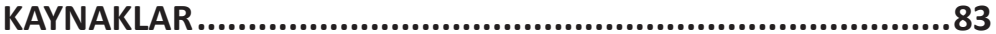




\section{KAYNAKLAR}

1. Urfalığlu, F. ve Genç, T. (2013). Çok Kriterli Karar Verme Teknikleri ile Türkiye’nin Ekonomi Performansının AB üye Ülkeleri ile Karşılaştırılması, Marmara Üniversitesi İİB Dergisi, 35(2), 329-360.

2. Mardani, A., Jusoh, A.,Nor K.MD.,Khalifah, Z.,Zakwan, N. ve Valipour, A. (2015). Multiple criteria decision-making techniques and their applications - a review of the literature from 2000 to 2014, Economic Research-Ekonomska Istraživanja, 28(1), 516-571.

3. Yu, P.L. (1985).”Multiple Criteria Decision Making Concepts, Techniques and Extensions", Mathematical Concepts and Methods in Science and Engineering.

4. Tepe, S. ve Görener, A. (2014). Analitik Hiyerarşi Süreci ve Moora Yöntemlerinin Personel Seçiminde Uygulanması, İstanbul Ticaret Üniversitesi Fen Bilimleri Dergisi, 13(25), 1-14.

5. Saaty, T.L. (1986). Axiomatic Foundation of the Analytic Hierarchy Process, Management Science, 32 (7), 841-855.

6. Brauers, W. K. M. (2008). Multi-Objective Contractor's Ranking by Applying the MOORA Method. Journal of Business Economics and Management, (4), 245-255.

7. Kılıç, M. (2015). Yatırım Projelerinin Değerlendirilmesinde Bulanık Tabanlı Bir Yaklaşım, Yıldız Teknik Üniversitesi Fen Bilimleri Enstitüsü Endüstri Mühendisliği Ana Bilim Dalı Doktora tezi, İstanbul.

8. Dağdeviren, M. ve Eraslan, E. (2008). PROMETHEE sıralama yöntemi ile tedarikçi seçimi, Gazi Üniversitesi Mühendis ve Mimarlar Dergisi, 23(1), 69-75.

9. Önder, E., Yıldırım, B.F. (2015). Operasyonel, Yönetsel ve Stratejik Problemlerin Çözümünde Çok Kriterli Karar Verme Yöntemleri, Dora, ISBN:978605-9929-44-8

10. Ertuğrul, İ. ve Karakaşoğlu, N. (2010). ELECTRE ve Bulanık AHP yöntemleri ile Bir İşletme İçin Bilgisayar Seçimi, 25(2), 23-41. 
11. Karaatlı, M., Ömürbek, N. ve Köse, G. (2014). Analitik Hiyerarşi Süreci Temelli VIKOR ve TOPSIS yöntemleri ile Futbolcu Performanslarının Değerlendirilmesi, Dokuz Eylül Üniversitesi İktisadi ve İdari Bilimler Dergisi, 29(1), 25-61.

12. Özdemir, M., Çelikbilek, Y. (2020). Açıklamalı ve Karşılaştırmalı Sağlık Bilimleri Uygulamaları ile Çok Kriterli Karar Verme Yöntemleri, Nobel, ISBN:978-625-402-069-8

13. Özdemir, A., Topal, M. (2019). Türk Eğitim Sisteminin Sorunlarının DEMATEL ve Analitik Ağ Süreci Yöntemleri Kullanılarak Değerlendirilmesi, Marmara Üniversitesi Atatürk Eğitim Fakültesi Eğitim Bilimleri Dergisi, 50, 160-184. 